\title{
Etika Bisnis Ditinjau Dari Perspektif Alkitab
}

\author{
Jacky Latupeirissa \\ Sekolah Tinggi Teologi Baptis Indonesia Semarang \\ jaecindo@yahoo.com
}

\begin{abstract}
ABSTRAK
Bisnis adalah sebuah dunia tersendiri yang terlepas dari nilai-nilai dan norma-norma kecuali peraturan yang berlaku saat itu, di tempat itu. Apa yang dilarang oleh peraturan, boleh jadi menjadi legal di waktu mendatang sehingga etika tidak lebih dari seperangkat peraturan yang dapat berubah tergantung situasi. Pertanyaannya adalah apa yang terjadi dengan etika bisnis sebagai standar untuk pengambilan keputusan etis dan bagaimana peranan agama sebagai keyakinan yang mengajarkan takut akan Tuhan? Berbisnis dimaksudkan untuk mengasihi sesama manusia.Artinya, mengasihi pekerjanya, mengasihi rekan kerjanya, dan mengasihi konsumen atau pelanggannya. Bagian Alkitab yang menjadi dasar interpretasi teologis dari bisnis Kristen, yaitu: Kegiatan Bisnis untuk Memenuhi Mandat Ilahi yaitu Menguasai dan Melestarikan Ciptaan (Kejadian 1:26-28; 2:5,15); , Kegiatan Bisnis sebagai Aktivitas Kerja dan Pelayanan (Kejadian 3:17-19; 2 Tesalonika 3:10); , Kegiatan Bisnis Digunakan untuk Memuliakan Tuhan (Mazmur 150; Roma 11:36); , Menjadi Garam dan Terang di Pilar Bisnis dan Ekonomi (Matius 5:13-14), Usaha Atau Bisnis Adalah Suatu Alat Bukan Tujuan.
\end{abstract}

Kata kunci: Bisnis, Ekonomi, Alkitab, Etika, Kristen.

\section{PENDAHULUAN}

Seorang teman berkata bahwa bisnis itu buta etika, buta segala-galanya kecuali uang. Dengan kata lain dia mengatakan bahwa bisnis adalah sebuah dunia tersendiri yang terlepas dari nilai-nilai dan normanorma kecuali peraturan yang berlaku saat itu, di tempat itu. Apa yang dilarang oleh peraturan, boleh jadi menjadi legal di waktu mendatang sehingga etika tidak lebih dari seperangkat peraturan yang dapat berubah tergantung situasi. Pertanyaannya adalah apa yang terjadi dengan etika bisnis sebagai standar untuk pengambilan keputusan etis dan bagaimana peranan agama sebagai keyakinan yang mengajarkan takut akan Tuhan? Seperti yang dikatakan Firman Tuhan, "Karena akar segala kejahatan ialah cinta uang. Sebab oleh memburu uanglah beberapa orang telah menyimpang dari

\footnotetext{
${ }^{1}$ Karel Sosiopater, Etika Bisnis (Jakarta: Suara Harapan Bangsa, 2013), 1
}

iman dan menyiksa dirinya dengan berbagaibagai duka (I Timotius 6:10).

Kejadian 1 menjelaskan bahwa Allah menciptakan segala materi dan makhluk yang ada di dunia ini (Kej. 1:1-31). Sebagian besar materi ciptaan tersebut bisa menjadi materi bisnis. Manusia tercipta sebagai "makhluk sosial" yang terkait dengan masalah ekonomi untuk hidup. Dalam arti bahwa manusia harus berjuang untuk "kehidupannya" melalui bidang pertanian maupun perdagangan. Akibat dosa maka manusia akan banyak menghadapi tantangan dalam mencari makanan atau berbisnis, terjadinya persaingan jutaan manusia di suatu daerah (Kej. 3:17-19). Karena itulah perlu ada norma untuk menata dan mengatur perekonomian untuk kesejahteraan manusia bersama. ${ }^{1}$ Di sinilah peran etika bisnis Kristen.

Di samping itu juga orang Kristen seringkali menemukan pertentangan ketika menerapkan prinsip-prinsip Alkitabiah dalam 
menjalankan bisnisnya.Karena tujuan daripada bisnis adalah meraih keuntungan sebesar-besarnya.Juga ada anggapan bahwa "bisnis itu kotor" bukanlah untuk orangorang jujur, saleh dan bermoral, sehingga orang percaya tidak boleh terlibat di dalamnya. Untuk itulah muncul pertanyaan sejauh mana keterlibatan orang Kristen dalam praktik bisnis dan bagaimana seharusnya bisnis yang alkitabiah. Melihat dari hal tersebut, bisnis merupakan hal yang kompleks karena terkait dengan banyak bidang kehidupan manusia dan karenanya perlu dipikirkan dengan baik.

\section{PEMBAHASAN \\ Pengertian Etika Bisnis Kristen}

Etika berasal dari kata Yunani yaitu ethos artinya kebiasaan, adat. Berarti kesusilaan, perasaan batin, atau kecenderungan hati dengan mana seseorang melaksanakan sesuatu perbuatan. ${ }^{2}$ Etika berhubungan erat dengan kelakuan manusia dan cara manusia melakukan perbuatannya. Itu menunjuk pada dua hal yakni positif dan negatif. Oleh sebab itu tugas etika adalah menyelidiki, mengontrol setiap perbuatanperbuatan, mengoreksi, dan membimbing serta mengarahkan suatu tindakan yang seharusnya dilakukan agar dapat memperbaiki tindakan atau perbuatannya. ${ }^{3}$ Istilah bisnis berarti usaha dagang. Bisnis merupakan hubungan antar manusia, yang saling "membutuhkan" pada posisi yang berbeda, seperti seorang penjual dan pembeli.Dengan adanya kegiatan bisnis maka kebutuhannya saling terpenuhi. ${ }^{4}$ Bisnis adalah suatu usaha atau serangkaian usaha yang dilakukan seseorang atau sekelompok orang maupun suatu organisasi dengan menawarkan barang dan jasa untuk mendapatkan keuntungan (laba).

Berdasarkan pengertian etika bisnis di atas maka bisnis apa pun, termasuk bisnis yang dijalankan oleh seorang Kristen

\footnotetext{
2 J. Verkuyl, Etika Kristen Bagian Umum (Jakarta: BPK Gunung Mulia, 1996), 1.

${ }^{3}$ R. M. Drie Brotosudarmo, Etika Kristen untuk Perguruan Tinggi (Yogyakarta: ANDI, 2010), 5.

${ }^{4}$ Karel Sosiopater, 32.
}

haruslah mampu mendatangkan laba (keuntungan) agar usahanya dapat langgeng tetapi tetap mengontrol tindakan berbisnisnya dalam perspektif kristen. Tidak ada larangan bagi orang Kristen untuk mendapatkan keuntungan dalam berbisnis. Namun, ada peringatan yang tegas dari Alkitab terhadap keuntungan gelap yang di dapat dari ketidakjujuran dan pengambilan hak orang lain. ${ }^{5}$

Alexander Hill mendefinisikan etika Kristen sebagai aplikasi dari nilai-nilai kristiani terhadap proses pengambilan keputusan. ${ }^{6}$ Sebagaimana etika umum mengacu kepada nilai dan norma dalam masyarakat, maka sebaliknya etika Kristen mengacu kepada kebenaran prinsip-prinsip firman Tuhan yang berlaku secara universal dan tidak pernah berubah. Etika bisnis Kristen merupakan usaha untuk menjelaskan dan menemukan kebenarankebenaran Ilahi yang terkait dengan ekonomi dan bisnis serta perilaku di dalamnya. Kepantasan dan ketidakpantasan dalam berbisnis serta perilaku pelaku bisnis merupakan hal yang harus ditemukan dalam etika bisnis Kristen. Sebagaimana etika Kristen sendiri berkaitan dengan apa yang dikehendaki Allah untuk dilakukan manusia yang diciptakan segambar dengan-Nya. Maka suatu prinsipprinsip Alkitabiah haruslah diterapkan dalam menjalankan bisnis tersebut.

Perhatikanlah dua ayat Alkitab berikut: "Siapa laba akan keuntungan gelap, mengacaukan rumah tangganya, tetapi siapa membenci suap akan hidup" (Amsal 15:27), dan "Celakalah dia yang telah membangun istananya berdasarkan ketidakadilan dan anjungnya berdasarkan kelaliman, yang akan mempekerjakan sesamanya dengan cuma-cuma dan tidak memberikan sedikit upahnya kepadanya" (Yeremia 22:13). Tony Evans, seorang pendeta dan teolog menuliskan, "Allah memberdayakan orang-orangNya untuk penggunaan yang benar dari sumber-sumber daya di bumi untuk secara menguntungkan (dan secara bermoral) melakukan bisnis sebagai para pengelolaNya". Karena itu, disinilah perlunya

\footnotetext{
${ }^{5}$ Larry Burkett. Kunci Sukses Bisnis Menurut Alkitab. (Yogyakarta: Penerbit Andi Offset, 1997), 12.

${ }^{6}$ Alexander Hill, Bisnis yang Benar (Bandung: Kalam Hidup, 2001), 10.
} 
membicarakan bisnis Kristen menurut pandangan Alkitab. ${ }^{7}$

Bisnis adalah usaha dan pada umumnya adalah hal yang sama dimanamana, tetapi motivasi untuk melakukan bisnis serta nilai-nilai dan cara yang dikembangkan di dalam berbisnis dapat berbeda-beda. Setiap pelaku bisnis seharusnya memahami asas atau nilai-nilai Kristen yang harus dikembangkan di dalam setiap aspek bisnis atau usaha. Seorang pengusaha Kristen harus mempunyai ciri kekristenan dalam dunia bisnis yang dikelola. Bisnis atau usaha harus dikelola secara profesional dengan dijiwai nilai-nilai dan semangat iman Kristen. Nilai-nilai iman Kristen di dalam berbisnis tidak bertentangan dengan prinsip profesionalisme, bahkan dapat dikatakan bahwa praktik bisnis yang profesional sebenarnya dikembangkan dari nilai-nilai Kristen.

\section{Tujuan Bisnis Kristen}

Pandji Anoraga menyebutkan empat tujuan bisnis secara umum, yaitu:

(1) Mencari keuntungan (profit);

(2) Mempertahankan kelangsungan usaha;

(3) Untuk pertumbuhan, pengembangan usaha;

(4) Dan sebagai tanggung jawab sosial.

Keempat tujuan tersebut saling terkait, karena keuntungan usaha digunakan untuk mempertahankan kelangsungan usaha dan mengembangkan usaha serta merupakan bukti pertanggunjawaban sosial berupa terbukanya lapangan pekerjaan. Sementara itu, secara khusus Larry Burkett menyebutkan bahwa apabila tujuan sebuah bisnis Kristen harus digunakan untuk melayani Allah, hanya ada satu maksud yang menonjol, yaitu memuliakan Dia. Ini merupakan tujuan setiap orang Kristen, dalam bisnis maupun dalam bidang lainnya (Kolose 3:23). Larry Burkett kemudian

\footnotetext{
${ }^{7}$ Paul L Cuny, Rahasia Ekonomi Kerajaan Allah. (Yogyakarta: Penerbit Andi Offset, 2012), 32.

${ }^{8}$ Daniel Ronda, Bisnis dalam Pandangan Alkitab. Diakses 2 November 2018,
}

menyebutkan lima tujuan (fungsi) bisnis Kristen, yaitu:

(1) Penginjilan, yaitu bahwa bisnis yang dipersembahkan kepada Tuhan adalah alat yang efektif bagi penginjilan

(2) Pemuridan, yaitu melatih orang-orang Kristen untuk tumbuh semakin kuat dalam iman mereka melalui kegiatan bisnis (2 Timotius 2:2);

(3) Memberi dana bagi pekerjaan Tuhan melalui bisnis dijalankan dengan semestinya (1 Timotius 3:15);

(4)Dalam Memenuhi kebutuhankebutuhan pemilik, karyawan, pelanggan, dan lainnya sebagainya; dan

(5) Mendapatkan keuntungan melalui perencanaan dan manajemen yang baik

dengan melibatkan Tuhan (Amsal 16:9; Amsal 13:4).

\section{Landasan Teologis-Alkitabiah dalam Berbisnis}

Perlu diperhatikan bahwa Alkitab sendiri memberikan dasar dalam berbisnis. Adalah kehendak Allah bagi manusia untuk bekerja, baik sebelum kejatuhan (Kejadian 1:28), maupun sesudah kejatuhan manusia (Kejadian 3:17-19). Sebelum kejatuhan, pekerjaan adalah suatu anugerah dan panggilan dari Allah sendiri.Sesudah kejatuhan, pekerjaan tetap merupakan anugerah dan panggilan, namun sekarang akibat dosa maka pekerjaan itu dilakukan dengan penuh persaingan. ${ }^{8}$

Di dalam Perjanjian Baru, Paulus menasihatkan jemaat bahwa hendaklah bekerja. Ia juga memperingatkan bahwa, "Jika seorang tidak mau bekerja, janganlah ia makan" (II Tesalonika 3:10b). Jadi berkerja merupakan anugerah dan panggilan bagi orang Kristen. Itulah sebabnya seorang Kristen harus bekerja bahkan bekerja dengan giat dan keras. Maka yang menjadi dasar etika Kristen untuk bisnis adalah hukum "kasih" (Mat. 22:37- 39). ${ }^{9}$

Berbisnis dimaksudkan untuk mengasihi Tuhan Allah.Artinya, sebagai ciptaan yang diciptakan segambar dengan Allah, bekerja atau berbisnis mempunyai makna ilahi tetapi kita sedang melayani Allah.Berbisnis dimaksudkan

http://danielronda.blogspot.com/2008/04/bisnis-dalampandangan-alkitab.html.

${ }^{9}$ Karel Sosiopater, 70-76. 
untuk mengasihi diri sendiri. Artinya, Allah menghendaki kita menjadi produktif, rajin bekerja dan mandiri terhadap kebutuhan pokok sendiri dan bukannya malas ( 2 Tes. 3:10). Berbisnis dimaksudkan untuk mengasihi sesama manusia.Artinya, mengasihi pekerjanya, mengasihi rekan kerjanya, dan mengasihi konsumen atau pelanggannya.

Bagian Alkitab yang menjadi dasar interpretasi teologis dari bisnis Kristen, yaitu:

1.Kegiatan Bisnis untuk Memenuhi Mandat Ilahi yaitu Menguasai dan Melestarikan Ciptaan (Kejadian 1:26-28; 2:5,15);

Manusia mendapat mandat atau otoritas dari Allah untuk, menguasai, mengelola dan melestarikan ciptaanNya, serta menjalankan hidup mereka. Dalam Kejadian 1:26,28 Istilah Ibrani yang dipakai adalah "kavash (berkuasa)" dan "radah (berkuasalah)" mengandung arti bahwa manusia harus menguasai seluruh ciptaan Tuhan sebagaimana para raja Ibrani dikemudian hari menguasai rakyatnya. Raja-raja ini tidak boleh memerintah demi keuntungannya sendiri, melainkan demi kesejahteraan rakyat. Untuk melakukan tugas-tugas itu manusia diberi berkat dan kecerdasan berupa kemampuan, bakat, dan ketrampilan karena ia diciptakan menurut "gambar dan rupa Allah" (kejadian 1:26). Salah satu maksud Allah menciptakan manusia adalah untuk menjadi rekan kerjanya di dalam mengusahakan dan memelihara apa yang telah Tuhan diciptakan, karena hanya manusia saja yang punya kemampuan untuk melakukan dua hal tersebut; sedangkan ciptaan Tuhan lainnya tidak diperlengkapi dengan akal pikiran yang memungkinkan mereka melakukan kedua hal tersebut (Kejadiaan 2:15). Di dalam perintah Tuhan kepada manusia untuk mengusahakan itu tercakup tugas untuk mencari makanan bagi manusia itu sendiri; dan di dalam perintah untuk memelihara tercakup perintah untuk

${ }^{10}$ Paul L Cuny. Rahasia Ekonomi Kerajaan Allah (Yogyakarta: Penerbit Andi Offset, 2012), 22. menjaga kelestarian lingkungan hidup disekitarnya dan cara memeliharanya. Jadi siapa yang berusaha atau melakukan bisnis dengan memperhatikan lingkungan hidupnya sebenarnya sudah menaati perintah Tuhan. ${ }^{10}$

2.Kegiatan Bisnis sebagai Aktivitas Kerja dan Pelayanan (Kejadian 3:17-19; 2 Tesalonika $3: 10)$

Sebelum kejatuhan manusia dalam dosa, pekerjaan adalah suatu anugerah dan panggilan dari Allah sendiri (Kejadian 1:26-28; 2:5,15). Sesudah kejatuhan, pekerjaan tetap merupakan anugerah dan panggilan, namun sekarang akibat dosa maka pekerjaan itu dilakukan dengan penuh kerja keras dan persaingan. Di dalam Perjanjian Baru, Paulus menasehatkan jemaat agar bekerja dan Ia juga mengingatkan bahwa, "Jika seorang tidak mau bekerja, janganlah ia makan" (2 Tesalonika 3:10b). Karena bekerja adalah anugerah dan panggilan, maka sebaiknya babnya seorang Kristen haruslah bekerja dengan keras, cerdas, ikhlas, dan tuntas. Berdasarkan konsep Alkitab kerja adalah kegiatan yang mencakup segala sesuatu yang dilakukan di dalam kehidupan sehari-hari, untuk melangsungkan kehidupan, bukan hanya sekadar kerja dalam pengertian suatu usaha yang menghasilkan uang. Kerja adalah bagian dari kehidupan dan karakter hidup manusia, yang harus dilaksanakan. Kerja bukan merupakan suatu pilihan, tetapi keharusan. Kerja berkaitan dengan pelayanan atau melayani dan merupakan dimensi fundamental dari keberadaan manusia di dunia ini.

3.Kegiatan Bisnis Digunakan untuk Memuliakan Tuhan (Mazmur 150; Roma 11:36);

Larry Burkett menyatakan, "Maksud dari sebuah bisnis Kristen ialah memuliakan Allah". Allah memberikan mandat kepada manusia untuk menguasai dan melestarikan ciptaan serta memberikan kecerdasan kepada manusia berupa kemampuan bakat dan ketrampilan untuk melakukan aktivitas melalui pekerjaan, termasuk kegiatan bisnis. Karena itu, dalam aktivitas bisnisnya manusia harus mengerjakan dengan sebaik-baiknya dan bertanggung jawab. 
Melalui bisnis, manusia diajarkan untuk memuliakan Allah sebagai pemberi berkat. Hal ini merupakan bakti manusia kepada Allah. Karena kerja adalah bakti atau ibadah terhadap Allah, sekecil apa pun pekerjaan yang manusia lakukan, hal itu merupakan sumbangan secara tidak langsung bagi terwujudnya tujuan Allah dengan umat manusia. Jadi, pekerjaan, termasuk bisnis apa pun yang manusia lakukan adalah untuk kemuliaan Allah (1 Korintus 10:31). Kerja adalah dasar penyerahan diri manusia kepada Tuhan supaya Ia dapat menjadikan manusia alat-alat untuk melakukan pekerjaan-Nya di dunia ini. Perlu diingat bahwa dalam pandangan Kristen tujuan kerja dan bisnis bukan untuk gengsi dan kehormatan. Namun, tujuannya adalah bagi kemuliaan Allah dan pelayanan kepada sesama. $^{11}$

\section{Menjadi Garam dan Terang di Pilar Bisnis dan Ekonomi (Matius 5:13-14)}

Tujuan gereja yang terutama adalah memuliakan Allah dan menghadirkan kerajaan Allah di bumi ini dengan menjadi "garam" dan "terang" (Matius 5:13,14). Inilah dua kualitas transformatif yang harus dimanifestasikan gereja kepada dunia ini. Implikasi dari penegasan di atas cukup serius, yaitu bahwa orang Kristen secara universal harus memikul beban moril dari metafora "garam" dan "terang" tersebut secara konsisten dan konsekuen. Lebih jauh, implikasi ini bukan sekadar penegasan, tetapi merupakan sebuah panggilan bagi orang Kristen untuk melibatkan diri dan memberi solusi dalam masalah-masalah di dunia ini tanpa harus menjadi duniawi. Tuhan menginginkan kita melakukan pekerjaan-pekerjaan yang baik di semua aspek kehidupan kita dan di semua pilar masyarakat. Pernyataan klasik rasul Paulus tentang keselamatan "karena kasih karunia oleh iman" adalah frase Yunani "tê gar khariti este sesôsmenoi dia tês pisteôs" yang diterjemahkan "Sebab adalah karena kasih karunia kamu telah diselamatkan melalui iman" dalam Efesus 2:8, langsung diikuti oleh pernyataan ini "Karena kita ini buatan Allah, diciptakan dalam Kristus Yesus untuk melakukan pekerjaan baik, yang dipersiapkan Allah sebelumnya. Ia mau, supaya kita hidup di dalamnya" (Efesus 2:10). Frase Yunani "pekerjaan baik" dalam ayat ini adalah "ergois agathois" diterjemahkan "perbuatanperbuatan yang baik". Kata "agathois" berasal dari kata "agathos" yaitu kata Yunani yang biasa digunakan untuk menerangkan gagasan yang "baik" sebagai kualitas jasmani atau moral. Kata ini dapat berarti "baik, mulia, patut, yang terhormat, dan mengagumkan". Karena kemampuan berbisnis adalah alat (sarana) yang dapat digunakan untuk mengekspresikan bakat, talenta, dan kemampuan dari kecerdasan yang dianugerahkan Tuhan kepada kita, maka hal itu haruslah dipakai untuk melakukan pekerjaanpekerjaan yang baik bagi sesama dan memuliakan Tuhan (Roma 11:36).

\section{Usaha Atau Bisnis Adalah Suatu Alat Bukan Tujuan.}

Perlu dipahami bahwa berusaha atau berbisnis hanya berfungsi sebagai alat saja agar hidup manusia dapat terpelihara. Bisnis bukan segala-galanya dan bukan menjadi tujuan hidup manusia. Artinya seorang Kristen tidak boleh lupa akan Tuhan, keluarga, tujuan hidupnya dan kehidupan bergereja bersama-sama saudara seiman lainnya. Setiap orang Kristen harus mengingat bahwa ada tugas mulia yang dimandatkan oleh Tuhan Yesus agar menjadi garam dan terang bagi dunia ini. Tugas mulia ini harus tetap dibawa dan dijalankan di dunia bisnis yang dilakukan. Hal ini bukan menunjukkan kefanatikan seseorang tetapi menunjukkan bahwa ia tahu tugas dan tanggung jawabnya dihadapan Allah. Membawa terang Tuhan ke dalam dunia bisnis tidak bertentangan atau menutup kemungkinan seorang Kristen untuk menjadi pengusaha sukses atau kaya raya, sejauh ia tetap menjalankan usahanya dengan cara-cara yang sehat. Contohnya nyata dari Alkitab adalah Abraham, bapa orang beriman, ia adalah seorang pengusaha ternak terkaya pada zamannya. Demikian juga Ishak, putranya sangat kaya. Dengan memahami bahwa bisnis atau usaha hanyalah suatu alat untuk memelihara kehidupan, maka bukanlah hal yang salah bila seorang Kristen atau pun seorang hamba Tuhan

${ }^{11}$ Ibid., 24. 
(pendeta) juga melakukan usaha atau bisnis tertentu sebagaimana yang telah dilakukan oleh rasul Paulus, yaitu dengan berjualan tenda. Paulus melakukan hal itu agar kebutuhan hidup dan pelayanannya dapat terpenuhi tanpa mengganggu kehidupan jemaat lainnya (Kisah Para Rasul 18:1-3).

\section{Perilaku Etis dalam Berbisnis Secara Kristen}

Etika adalah pengetahuan tentang nilai-nilai baik atau buruk, benar atau salah, dan berhubungan dengan moralitas yang dijadikan sebagai acuan, aturan, standar, atau norma yang berlaku. Jadi, etis adalah hal-hal yang sesuai dengan etika, yaitu aturan, standar, atau norma yang berlaku dalam kelompok atau masyarakat tertentu. Dalam konteks iman Kristen ukuran apa yang baik adalah segala sesuatu yang sesuai dengan kehendak Tuhan. Kehendak Tuhan itu sendiri telah dinyatakan dalam Alkitab (2 Timotius 3;16). Jadi, titik tolak berpikir etika Kristen adalah iman kepada Tuhan yang telah menyatakan diri di dalam Tuhan Yesus Kristus. Etika Kristen merupakan tanggapan akan kasih Allah yang menyelamatkan kita (1 Yohanes 4:19). Dalam etika Kristen kehendak Tuhan dikedepankan sehingga sifat etika Kristen adalah teologis dan imani. Kehidupan etis merupakan cara hidup dalam persekutuan dengan Tuhan. Dalam etika Kristen, kewibawaan Tuhan Yesus Kristus diakui. Karena itu berikut ini beberapa perilaku etis dalam berbisnis secara Kristen. ${ }^{12}$

\section{Menjalankan Bisnis yang Mencerminkan Kristus.}

Dunia bisnis tidaklah selalu jujur. Karenanya tiap orang Kristen wajib hidup dalam kejujuran. Tuhan sendiri berkata bahwa Ia bergaul erat dengan orang jujur (Amsal 3:32). Setiap pelaku bisnis pasti mencari untung dan semua orang mengetahui hal itu. Tidak mungkin ada sebuah bisnis berjalan bila tidak ada keuntungan. Tetapi hendaklah keuntungan bukan satu-satunya tujuan dalam praktik bisnis, sebab bila demikian seseorang yang akan berupaya menghalalkan segala cara untuk mencapai untung. Padahal setiap perilaku orang percaya ada di bawah terang Kristus.

\section{Menjalankan Bisnis yang Bertanggung Jawab.}

Pengusaha Kristen harus melakukan kegiatan bisnisnya dengan penuh tanggung jawab. Bertanggung jawab di dalam memproduksi, bertanggung jawab di dalam penjualan, bertanggung jawab di dalam mempromosikan dan bertanggung jawab di dalam pembayaran kewajiban dan hutang/pinjaman mereka. Tidak boleh ada pengusaha Kristen yang bisa membeli barang tetapi tidak bisa membayarnya, atau kabur begitu saja tanpa pemberitahuan atau tanggung jawab. Hal yang demikian sangat tidak terpuji dan tidak menjadi kesaksian yang baik di mana mereka harus menjadi garam dan terang (Mazmur 37:1). Selain itu, pelaku bisnis mampu bekerjasama dengan orang lain dan bisa menerima masukan dari beberapa rekannya (termasuk pasangannya); menyediakan produk yang bermutu dengan harga yang sesuai; menghormati orang yang memberi hutang kepada Anda (Amsal 3:27-28); memperlakukan bawahan dan karyawan dengan adil terutama dalam hal upahnya; dan menjadikan pelanggan atau orang yang menikmati produk atau jasa Anda sebagai yang utama. Jangan menipu mereka!

\section{Menerapkan Nilai Kejujuran}

Di dalam melakukan usaha atau bisnis, pengusaha Kristen tidak boleh mengikuti caracara dunia yang penuh kecurangan dan penipuan, baik di dalam ukuran barang, berat barang, kualitas, harga, maupun di dalam mempromosikannya. Orang-orang dunia hanya mengejar keuntungan saja, namun pengusaha Kristen juga harus mengusahakan kesaksian yang baik. Seorang pengusaha Kristen tidak boleh menunda menepati janji untuk membayar apa yang sudah dibelinya dengan cara mengatakan kebohongan-kebohongan seperti "boss tidak ada di tempat", "belum ada pemasukan", "pembeli-pembeli masih banyak

\footnotetext{
${ }^{12}$ Bertens, Etika. Edisi Revisi. (Yogyakarta:

Penerbit Kanasius: 2013), 36.
} 
yang belum membayar" dan lain-lain kebohongan seperti yang biasa dilakukan oleh orang-orang dunia. Seorang pengusaha Kristen tidak boleh lalai dalam membayar hutang-hutangnya sesuai kesepakatan yang telah dibuat. Seorang pengusaha Kristen harus dapat dipegang janjinya dengan berpedoman pada prinsip Alkitab yaitu : "ya katakan ya, tidak katakan tidak". Pengusaha Kristen Harus jujur dan bertanggung jawab (Amsal 11:1; 20:23; Mikha 6:11). ${ }^{13}$

\section{Memberikan Pelayanan yang Baik.}

Dikalangan usaha atau bisnis dikenal ungkapan "pelanggan adalah raja", yaitu suatu upaya memperlakukan para pelanggan mereka dengan baik, ramah dan memperhatikan apa yang menjadi kepentingan pelanggan. Prinsip ini dilandasi oleh semangat kerendahan hati untuk menganggap orang lain lebih utama. Ungkapan lainnya seperti "jemput bola" adalah suatu inisiatif yang dilakukan untuk bergerak memberikan pelayanan yang baik terlebih dahulu dan bukan menunggu sampai dikejar-kejar oleh orang lain. Ini adalah suatu prinsip dasar di dalam melayani yang diajarkan oleh Tuhan Yesus. Orang Kristen harus dapat memberikan pelayanan yang baik tanpa harus diminta. Pengusaha Kristen seharusnya dapat melakukan yang lebih baik lagi dalam hal pelayanan yang berhubungan dengan bisnis atau usaha, melebihi standar yang ada pada umumnya dengan demikian menunjukkan kelebihan nilai-nilai iman Kristen. Jika kita melakukan hal yang baik dan menyenangkan maka relasi kita akan senang berhubungan atau berbisnis dengan kita (Galatia 6:7; Filipi 2:3-4). ${ }^{14}$

\section{Melakukan Kewajiban Terhadap Karyawan dengan Benar}

Seorang pengusaha Kristen juga harus menjadi teladan bagi karyawannya dan bukan hanya bagi relasi bisnisnya. Dengan menjadi teladan yang baik bagi karyawannya pengusaha Kristen telah menjadi saksi Kristus di lingkungan

\footnotetext{
${ }^{13}$ Yakoep Ezra, Succes Through Character.
} (Yogyakarta: Penerbit Andi, 2006), 21. perusahaan yang dipimpinnya atau usaha yang dikelolanya. Hal utama bagi seorang pengusaha Kristen terhadap karyawannya adalah melakukan kewajibannya dengan baik, terutama di dalam pembayaran upah karyawannya. Pembayaran gaji karyawan yang dilaksanakan tepat waktu telah merupakan bukti dari tanggung jawab seorang pimpinan yang baik. Karena untuk mendapatkan gajilah maka para karyawan bekerja dengan baik, sehingga gaji yang adalah hak karyawan harus dibayar tepat waktu, utuh tanpa pemotongan yang tidak jelas (Roma 4:4; 1 Timotius 5:18; Yakobus 5:4; Bandingkan Yeremia 22:13).

\section{Menaati Peraturan dan Melakukan Kewajiban-Kewajiban}

Di dalam melakukan bisnisnya, pengusaha Kristen harus mematuhi peraturan-peraturan yang telah ditetapkan oleh pemerintah, baik melalui departemen terkait ataupun melalui pemerintah daerah setempat. Pemerintah yang baik adalah perpanjangan tangan Tuhan di dalam mengatur suatu negara agar semua komponen negara dapat berjalan dengan tertib dan tidak merugikan pihak-pihak lain. Orang Kristen, termasuk juga pengusaha Kristen harus tunduk kepada pemerintah (Roma 13:1-4; Titus 3:1). Pengusaha Kristen juga harus memenuhi apa yang menjadi kewajibannya terhadap pemerintah, mulai dari pembayaran listrik, air, telepon hingga pembayaran pajak-pajak dan rekening lainnya (Matius 22:21; Roma 13:6-7). 15

\section{Melakukan Bidang Usaha yang Baik dan Membangun}

Pengusaha Kristen dituntut untuk menjadi pengusaha yang membangun, artinya melakukan usaha atau bisnis yang tidak merusak dan merugikan orang lain dan lingkungan alam serta sosial dilingkungan kita. Misalnya seorang pengusaha Kristen tidak boleh menjadi pengusaha permainan judi, buka usaha pelacuran yang berkedok karaoke, atau dalam contoh yang banyak kita temui adalah membungakan uang dengan tingkat bunga yang sangat tinggi. Seorang pengusaha Kristen harus menyadari bahwa ia adalah seorang saksi

\footnotetext{
${ }^{14}$ Ibid., 25 .

${ }^{15}$ Ibid., 27
} 
Kristus yang membawa damai sejahtera bagi dunia ini dan tidak boleh melakukan sesuatu yang bertentangan dengan hukum kasih Allah dan Firman Allah (Efesus $2: 10) .{ }^{16}$

\section{KESIMPULAN}

Orang-orang dunia melakukan bisnisnya sebagai tujuan dan sebagai ukuran dari keberhasilan hidup mereka. Mereka melakukan bisnis siang dan malam karena itulah satu-satunya arti hidup bagi mereka dan mereka melakukannya tanpa mengandalkan atau melibatkan Tuhan. Berbeda dengan orang Kristen, bisnis dalam kekristenan tidak dapat dilepaskan dari keimanan dan campur tangan Tuhan. Tuhan peduli dengan bisnis yang dilakukan oleh anak-anakNya. Tuhan sebagai Bapa ingin melihat usaha atau bisnis anak-anakNya berhasil, dan Ia ingin memberkati usaha anak-anakNya (Ulangan 28:8-11).

Lakukanlah bisnis sesuai dengan perilaku etis Kristen dan berlandaskan Alkitab. Tuhan Yesus pasti dimuliakan melalui kehidupan kita.

\section{DAFTAR PUSTAKA}

Basden (Ed.), Paul A. Six View On Exploring The Worship Spectrum. Grand Rapids, Michigan: Zondervan

Bertens, Etika. Edisi Revisi. Yogyakarta: Penerbit Kanasius: 2013.

Blomberg, Craig. Tidak Miskin Tetapi Juga Tidak Kaya. Jakarta: Penerbit BPK Gunung Mulia, 2011.

Burkett, Larry. Kunci Sukses Bisnis Menurut Alkitab. Yogyakarta: Penerbit Andi Offset, 1997.

Cuny, Paul L. Rahasia Ekonomi Kerajaan Allah. Yogyakarta: Penerbit Andi Offset, 2012.

Drie Brotosudarmo,R. M. Etika Kristen untuk Perguruan Tinggi. Yogyakarta: Penerbit ANDI, 2010.

Ezra, Yakoep. Succes Through Character. Yogyakarta: Penerbit Andi, 2006.

Hill, Alexander. Bisnis yang Benar. Bandung: Kalam Hidup, 2001.

Sosiopater, Karel. Etika Bisnis. Jakarta: Suara Harapan Bangsa, 2013.

Verkuyl, J. Etika Kristen Bagian Umum. Jakarta: BPK Gunung Mulia, 1992.

\footnotetext{
${ }^{16}$ Craig Blomberg, Tidak Miskin Tetapi Juga Tidak 2011), 47.
} Kaya. (Jakarta: Penerbit BPK Gunung Mulia, 